UDK [272-789.45+272-789.5] (497.523Varaždin)“16”(091)

37.014(497.523Varaždin)“16”(091)

Izvorni znanstveni rad

Primljeno: 8. srpnja 2020.

Prihvaćeno za objavljivanje: 4 . prosinca 2020.

\title{
ISUSOVCI I SURADNJA S URŠULINKAMA PREMA PRVOJ SAMOSTANSKOJ KRONICI URŠULINSKOG SAMOSTANA U VARAŽDINU
}

\author{
Marija PEHAR \\ Katolički bogoslovni fakultet Sveučilišta u Zagrebu \\ Vlaška 38, p.p. 432, 10001 Zagreb \\ m.marijape@gmail.com
}

Rad tematizira ranu povijest odgojno-obrazovnoga rada sestara uršulinki u Varaždinu, od njihova dolaska 1703. godine do početka 20. stoljeća. Riječ je o odgojnom i školskom radu koji svojom kvalitetom, kako na europskoj tako i na hrvatskoj razini, nadmašuje stoljeća, a temeljio se na spisima utemeljiteljice reda sv. Anđele Merici i isusovačkoj uredbi o studiju $u$ srednjim i visokim školama Ratio studiorum. Zbog uočene duhovne i pedagoške sličnosti tih dviju redovničkih ustanova, a osobito zbog prostorno-vremenske koegzistencije u Varaždinu 18. i 19. stoljeća, logično se nametnulo pitanje o mogućoj suradnji dviju redovničkih zajednica na prosvjetnom i odgojnom planu, odnosno mogućem utjecaju isusovaca na ustroj i djelovanje uršulinskih škola i uopće njihovo odgojno-obrazovno djelovanje. Istraživanje je provedeno na Prvoj samostanskoj kronici uršulinskoga samostana u Varaždinu, koja bilježi vrijeme od dolaska uršulinki u Hrvatsku do 1900. godine, te ukazuje na duboku duhovnu i karizmatsku bliskost isusovaca i uršulinki, bogatu svećeničku djelatnost isusovaca u uršulinskom samostanu i crkvi, ali i zavidnu autonomiju koju su sestre imale u svom odgojno-obrazovnom djelovanju.

KLJUČNE RIJEČI: uršulinke, isusovci, Varaždin, uršslinska pedagoška načela, 18. i 19. stoljeće.

\section{Uvod}

Redovnice uršulinke bile su po mnogo čemu radikalna novost svoga vremena. Red je nastao u Italiji prvoj polovici 16. stoljeća, od utemeljiteljice sv. Anđele Merici prvo zamišljen kao oblik posvećenog života za žene u svijetu po uzoru na djevice prvih kršćanskih stoljeća, ali je nakon Tridentskog koncila transformiran na monastički oblik život sa strogom papinskom klauzurom. Uršulinke i u tim promijenjenim prilikama ustrajavaju na predanom odgojno-obrazovnom apostolatu, koji su njegovale od početka te pronalaze načina da ga povežu s tadašnjim pravilima kontemplativnoga života i stroge klauzure. Kroz to vrijeme preobrazbe, uz goleme poteškoće trude se sačuvati snažan duh utemeljiteljice 
i njezina kršćanskim duhom prožeta pedagoška načela. Tim je nastojanjima obilježeno i njihovo djelovanje u Hrvatskoj od samoga početka. U svom se odgojno-obrazovnom apostolatu oslanjaju na sve one materijalne, duhovne i intelektualne snage svoga vremena u kojima prepoznaju ideje i sadržaje slične svom djelovanju, prije svega kršćanskom odgojno-obrazovnom djelovanju za kojim su vapile europske zemlje u posttridentskim stoljećima. U tom kontekstu zanimljivo je ispitati je li i u kolikoj mjeri u prvom stoljeću sestarskoga djelovanja (18. stoljeću) u Hrvatskoj postojala suradnja uršulinki i isusovaca, tada veoma zauzetih na području školstva, odnosno može li se govoriti o utjecaju isusovaca na tadašnji odgojni i školski rad sestara uršulinki. Zbog prostorne blizine i razdoblja u kojemu se obje redovničke zajednice odlikuju značajnom i zapaženom odgojno-obrazovnom djelatnošću te na tom području, osobito na sjeveru Hrvatske ostavljaju neizbrisiv pečat, a osobito zbog sličnosti temeljne motivacije i kršćanskih sadržaja kojima su vođeni u obrazovanju muške i ženske mladeži, pretpostavljamo da su postojali intenzivniji kontakti te da su isusovci zbog većeg iskustva i dominantnijeg položaja u Crkvi i društvu mogli utjecati na odgojno-obrazovni rad hrvatskih uršulinki, poticati ga, pomagati i usmjeravati. Na početku, nakon kratkog iznošenja povijesnoga konteksta društveno-političkih zbivanja, osobito stanja hrvatskoga školstva u vremenu dolaska uršulinki u Hrvatsku, donosimo sažeto temeljne odlike uršulinskih škola i temeljna načela njihova pedagoškoga rada, čime se želi ukazati na logičnost očekivanoga povezivanja s isusovcima i njihovom djelatnošću na području odgoja i školstva. Konačno, kroz konkretne zabilješke uršulinske Prve samostanske kronike, koja bilježi vrijeme od dolaska uršulinki u Hrvatsku do 1900. godine, pratit ćemo kontakte uršulinki i isusovaca u tom razdoblju, s primarnom nakanom da se istraži je li i u kojoj mjeri bilo sudjelovanja isusovaca u aktivnostima uršulinskih škola i uopće njihova odgojno-obrazovnoga rada.

\section{Povijesni kontekst i stanje školstva u vrijeme dolaska uršulinki u Hrvatsku}

Dolazak uršulinki u Hrvatsku, Varaždin 1703. godine, dakle na samom prijelazu dvaju stoljeća, uklapa se u kontekst važnih povijesnih previranja na europskoj razini, a još više u Hrvatskoj. U Europi je to doba, s jedne strane velikog duhovnog preporoda, a s druge strane, širenja galikanizma, apsolutizma, jansenizma, koji su veoma naštetili Crkvi. Veliki problemi za Crkvu svakako su dugotrajne i nemale posljedice raskola s protestantizmom. Ali osjeća se također i novi zamah katolicizma u Europi, koji je započeo s Tridentskim koncilom. Austrijska politika i dobar dio Europe, osobito Hrvatska, još su snažno obilježeni borbom s Turcima. Neposredno prije dolaska uršulinki u Hrvatsku dovršava se postupno oslobođenje hrvatskih zemalja od turske vlasti (od 1683. do 1699.) i vraćanje gotovo čitave Slavonije, Hrvatske do Une i južnog Velebita pod vlast bečkoga dvora. Austrija u to vrijeme postaje velesila koja i Hrvatsko-Ugarskom Kraljevstvu nameće svoju nasljednu vlast. Nakon smrti Karla III. nasljednica njegova prijestolja po Pragmatičkoj sankciji ${ }^{1}$ postaje 1740. godine njegova najstarija kći Marija Terezija, koju su i Hrvati priznali za svoju kraljicu. ${ }^{2}$

1 Usp. Ferdo ŠIŠIĆ, Hrvatska povijest, II. dio: od godine 1526 do godine 1790., Zagreb, 1908., str. 127-140.

2 Ive MAŽURAN, Povijest Hrvatske od 15. do 18. stoljeća, Zagreb, 1998., str. 254-261. 
U skladu s duhom kulturnoga i vjerskoga preporoda tadašnje Europe, kulturna i vjerska događanja u sjevernim hrvatskim krajevima u koje dolaze uršulinke u to su vrijeme veoma bogata. Obilježava ih prije svega spomenuta snažna katolička obnova, čiji su nositelji ovdje bili uglavnom isusovci. U duhu katoličke obnove odgajali su mlade ljude u svojim školama i zavodima. U prvoj polovici 17. stoljeća otvarali su u hrvatskim gradovima (Zagreb, Rijeka, Dubrovnik, Varaždin) gimnazije u kojima se poučavalo po tada najsuvremenijim metodama. U Zagrebu, Varaždinu i Rijeci osnivali su i konvikte ili internate za studente u kojima su ne samo stvarali materijalne uvjete za studij nego i odgojno djelovali. U Zagrebu, Rijeci i Požegi imali su akademije sa studijem filozofije i teologije. Njihov kolegij na Griču u Zagrebu (osnovan 1662.), na kojemu se osim teologije i filozofije poučavalo kanonsko i građansko pravo, poveljom cara Leopolda I. proglašen je 1669. godine akademijom koja je u svemu bila izjednačena sa sveučilištem. Isusovci su u svojim školama i akademijama razvili vlastiti odgojno-obrazovni sustav, opisan i određen u dokumentu Ratio atque Institutio Studiorum Societatis Iesu, skraćeno Ratio studiorum (1599.), koji je predstavljao temelj i nacrt studija u srednjim i visokim školama. Prema tom dokumentu, koji je plod rada najkompetentnijih isusovačkih pedagoga i učenjaka i njihova polustoljetnoga iskustva na vrsnim učilištima i školama, razlikuju se niže (studia inferiora) i više studije (studia superiora), ali se cjelokupno obrazovanje temelji na klasičnoj izobrazbi i kršćanskim moralnim načelima. Prema toj uredbi, koju su u to vrijeme preuzimale i mnoge druge škole i akademije, niži studiji je zapravo gimnazija koja je trajala šest godina i temeljila se na klasičnoj misli, gramatici i književnosti, a nastavni je jezik bio latinski. U isusovačkim gimnazijama, koje je pohađao i velik broj građanskih i seljačkih sinova, osim školske izobrazbe naglasak se stavljao i na kazališne predstave, dispute, školske vježbe, a osobito na katolički odgoj (kroz Marijine kongregacije i slično) i izgradnju snažnih moralnih načela. Akademije su pak nudile trogodišnji studij filozofije, te četverogodišnji studij teologije. Osim značajnoga obrazovnog i zapaženog svećeničkog rada, isusovci su se u Hrvatskoj uvelike bavili i onim kulturnim. U Hrvatskoj su se izuzetno trudili oko nacionalnoga i vjerskoga identiteta. Poznati su sastavljači prvih gramatika na hrvatskom jeziku (štokavskom i kajkavskom) te značajnih rječnika. Gradnjom svojih crkava promicali su u Hrvatskoj barokni stil te i na taj način povezivali Hrvatsku s tadašnjom Europom. ${ }^{3}$

Uz isusovce velik doprinos vjeri i kulturi te osobito obrazovanju toga vremena u Hrvatskoj daju i pavlini. Već 1503. godine oni su u Lepoglavi osnovali gimnaziju. A postigli su također da i njihov filozofsko-teološki studij, koji su uz gimnaziju imali već od 1582. godine, 1671. godine postane studium generale sa svim odlikama visokoškolske ustanove te $\mathrm{s}$ nastavnim programom koji je u svemu bio na tadašnjoj europskoj razini. ${ }^{4} \mathrm{U}$ studiju filozofije i teologije oslanjali su se na isusovački Ratio studiorum. Osim filozofske i teološke izobrazbe na tom je pavlinskom učilištu u duhu katoličke obnove poticano i kulturno-književno ozračje, unutar kojega su među profesorima i studentima stvarana brojna filozofska i književna djela značajna za hrvatsku kulturu. ${ }^{5}$ Dakako, navedene odgojno-obrazovne

3 Mijo KORADE, »Školstvo u Hrvata od 16. do 18. stoljeća«, Povijest Hrvata od kraja 15. stoljeća do kraja Prvoga svjetskog rata, knjiga 2, Zagreb, 2005., str. 331-338.

4 Usp. Franjo ŠANJEK, Kršćanstvo na hrvatskom prostoru, Zagreb, 1991., str. 270.

5 Više o značaju pavlinskoga školstva u Hrvatskoj vidi u: Antun CUVAJ, Građa za povijest školstva Kraljevine Hrvatske i Slavonije I, Zagreb, 1910., str. 99-100; Antun CUVAJ, Građa za povijest školstva Kraljevine Hrvatske i Slavonije II, Zagreb, 1910. str. 65-68. 
ustanove, kako isusovačke tako i pavlinske, bile su otvorene samo muškarcima. Ženama je u to vrijeme bilo namijenjeno vođenje kućanstva i obiteljski odgoj djece. To će se značajno promijeniti dolaskom sestara uršulinki u Hrvatsku.

\section{Dolazak uršulinki u Hrvatsku i njihov odgojno-obrazovni rad}

Sam grad Varaždin, u koji su iz Požuna 1703. godine došle prve uršulinke, krajem 17. i početkom 18. stoljeća doživljava veliki gospodarski i politički uspon (u njemu povremeno stoluje i Hrvatski sabor). U političkom, javnom, a osobito u kulturnom životu, grad postaje središte sjeverne Hrvatske. U njemu se osjećao duh tadašnjih europskih prijestolnica, poput Pariza, Beča i drugih gradova. Prve uršulinke, njih dvanaest, dolaze na poziv grofice Magdalene Drašković, čija je kći Ana Julijana tada bila redovnica uršulinka u Požunu. Grofica, zabrinuta za sudbinu svoje kćeri zbog tadašnjih neprilika izazvanih Rakoczyjevim ustankom u Ugarskoj, moli tamošnjeg kardinala i poglavaricu samostana da je s nekoliko redovnica pošalje u Varaždin, gdje mogu osnovati samostan. S obzirom na to da grofica pritom obećava svoju pomoć i zaštitu, pristaju sestre na taj novi korak, doživljavajući ga kao trenutak providnosti. ${ }^{6}$ Tako jedna Hrvatica, s. Ana Julijana Drašković, uršulinke, koje su tada bile internacionalna redovnička zajednica, predvodi u Hrvatsku i postaje prvom poglavaricom novoosnovane zajednice.

Sam početak u Varaždinu nije bio lagan, ali sestre svojim životom, zavidnom školskom izobrazbom i zauzetim prosvjetnim radom vrlo brzo osvajaju srca kako običnih ljudi tako i plemstva i svećenstva, koje im uvelike pomaže. Za početak svoga odgojnog rada ${ }^{7}$ nisu čekale neku veliku materijalnu pomoć i posebne pogodnosti, nego odmah počinju poučavati žensku djecu pisanju, čitanju i šivanju. Neposredno po dolasku, dakle već iste 1703. godine dok su još gostoprimstvom grofice Drašković stanovale u njezinoj kući izvan gradskih zidina, počele su poučavati djevojke te su otvorile dva razreda iz kojih će se kasnije razviti više vrsta škola. Godinu dana kasnije sele u novi iznajmljeni stan unutar grada, u kojemu su 1707. imale konvikt, a već 1708. kupuju i dvije trošne drvenjare, od kojih je jedna služila za samostan, a druga za školu i konvikt. ${ }^{8}$ Sve to svjedoči koliko im je na srcu bilo odgojno-obrazovno djelovanje i koliko su ga doživljavale kao svoje životno poslanje. U teškim materijalnim uvjetima na početku sestre su dobivale novčanu pomoć i posudbu iz svoje matične kuće u Požunu, a u svoj su apostolat uložile i vlastite miraze, darove koje su $\mathrm{u}$ to vrijeme uobičajeno dobivale redovnice od svojih obitelji prilikom ulaska u samostan i koji su trebali služiti njihovu uzdržavanju. ${ }^{9}$

6 Usp. Magdalena LONČARIĆ, »Podrške i potpore plemstva uršulinkama u Varaždinu«, 300 godina uršulinki u Varaždinu, Zbornik radova s međunarodnog znanstvenog skupa održanog 18. listopada 2003. godine u Varaždinu, Eduard VRAGOVIĆ - Klaudija ĐURAN (ur.), Varaždin, 2003., str. 67-77, ovdje 67.

7 O odgojno-obrazovnoj djelatnosti uršulinki, s osobitim naglaskom na djelovanje u Hrvatskoj, više vidi u: Hrvatske uršulinke, povodom 275. godišnjice osnutka Uršulinskog samostana u Varaždinu, Marija Assumpta SVALINA - Ana Klaudija ĐURAN (prir.), Varaždin, 1979., str. 75-133.

8 Usp. Klaudija ĐURAN, »Najpoznatije uršulinke varaždinskog samostana«, 300 godina uršulinki u Varaždinu, str. 93-127, ovdje 95-96. Usp. također Hrvatske uršulinke, str. 88-90.

9 Usp. A. CUVAJ, Građa za povijest školstva I, str. 346. 
Arhivski materijali uršulinskih odgojno-obrazovnih ustanova pružaju fascinantne podatke o pedagoškom radu i školama ovih sestara. Po vrsnoći njihove škole diljem Europe i pedagoški rad u njima prekoračuju stoljeća. U njima se radilo po tako visokim pedagoškim kriterijima da im bez sumnje na tomu može zavidjeti i naše vrijeme. U skladu sa svojim poslanjem odgojiteljica, uršulinke su kao internacionalna redovnička zajednica već od 1652. godine imale izrađene Upute i pravila uršulinki za odgojno-obrazovni rad, metodološki i metodički priručnik (Règlements des Ursulines). ${ }^{10}$ Ta su pravila bila analogna isusovačkoj uredbi Ratio studiorum i na njoj su se temeljila. Bila su »u neku ruku spoj isusovačke duhovnosti i duha Sorbonne i kao rezultat njihova kombiniranog utjecaja « ${ }^{11}$. Sudjelovanjem u izradi pariških Konstitucija za uršulinke iz 1646. godine isusovci su svoje odgojne metode predali pariškim uršulinkama, a od njih su ih preuzeli i ostali uršulinski samostani. Prema tim metodama naglašen je kako individualni tako i kolektivni obiteljski odgoj, a on obuhvaća odgoj razuma, volje i srca.

Ipak, kad je riječ o pedagoškim načelima uršulinskoga odgojnog djelovanja, treba reći da se ta načela prije svega vežu uz utemeljiteljicu reda sv. Anđelu Merici i njezine Spise. Njezine vizije podizanja žene u moralnom smislu, poučavanja ženske mladeži u vjerskim istinama, te na taj način obnove obitelji, svakako su prvi izvor uršulinske odgojno-obrazovne djelatnosti kroz stoljeća. Njezini Spisi kao temeljne pedagoške smjernice uršulinki otkrivaju okrenutost pojedinačnoj osobi i cjelovitu zauzetost oko odgajanica, njihovih sklonosti i intelektualnih sposobnosti, ali i njihove zrele afektivnosti. U središtu svega poučavanja uvijek je bio vjeronauk, poučavanje vjerskih istina. Spisi ističu poštivanje slobode, odgoj blagošću i strpljivošću. Iznad svega naglašavaju važnost osobnog primjera odgojiteljice, njezinu ljubav prema odgajanicama, razboritost, revnost i stručnost. Uršulinska škola tako je bila duhovna obitelj, a sestre ne samo učiteljice nego i majke svojim učenicama. A snažno se naglašavala prilagodljivost osobama, vremenu, novim metodama i potrebnim sadržajima, tako da su uršulinke brzo širile svoju djelatnost širom tadašnjega svijeta i pronalazile svoje mjesto u različitim prilikama. ${ }^{12}$

Uršulinske škole u Hrvatskoj ravnale su se također prema navedenim pedagoškim načelima kakva su vrijedila u svim tadašnjim uršulinskim školama. Suprotno tada raširenim stavovima da škole nisu potrebne širem puku, a pogotovo ne ženama, uršulinke otvaraju upravo škole u kojima primarno poučavaju žensku djecu. Sestre su ulagale sve snage da bi škole podigle i održale na zavidnoj razini, onako kako je to bilo i u drugim europskim državama iz kojih su dolazile. Uz suvremene pedagoške metode i kršćanski odgoj velika se pažnja posvećivala da se učenicama pribave potrebne sprave i priručna sredstva za oglede i učenje. Tako je, primjerice, školska knjižnica uršulinske gimnazije u Varaždinu posjedovala već dosta rano dragocjene i brojne naslove, suvremene knjige, enciklopedije, katekizme, bontone, moralne pouke, beletristiku, opsežne gramatike, udžbenike, glazbene knjige, notne zapise, štoviše, suvremene časopise. ${ }^{13}$

\footnotetext{
${ }^{10}$ Usp. Hrvatske uršulinke, str. 80.

11 Isto, str. 81.

12 Usp. Hrvatske uršulinke, str. 79-80; Usp. Marija Jasna KOGOJ, »Ustanovitev in razvoj uršulinskega reda ter njegovo mesto v Cerkvi«, 300 godina uršulinki u Varaždinu, str. 33-46.

${ }^{13}$ Usp. Hrvatske uršulinke, str. 99.
} 
Za tadašnje je hrvatske prilike važno spomenuti da su varaždinske uršulinke u svojim školama vrlo rano počele poučavati na hrvatskom jeziku. Iako je službenu odredbu o učenju narodnoga jezika u školama Kraljevsko vijeće Kraljevine Hrvatske, Slavonije i Dalmacije donijelo tek 1778. godine, potaknute crkvenim poglavarstvom uršulinke su to činile čak 64 godine ranije. To je veoma značajno, tim više ako znamo da je službeni jezik Austro-Ugarske Monarhije bio njemački, a uz to i većina tadašnjih uršulinki nije bila hrvatskog podrijetla. Unatoč tomu, na poticaj kanonskog vizitatora opata Nikole Gottala 1714. godine su uz njemački uvele učenje čitanja i pisanja na hrvatskom jeziku. Dakako, da bi mogle poučavati na hrvatskom, mnoge su morale i same učiti hrvatski jezik, što se kasnije ulaskom Hrvatica u samostan znatnije poboljšalo. ${ }^{14}$

O visokoj razini obrazovanja svjedoči i primjer učenja stranih jezika. U uršulinskim su školama strane jezike predavale sestre koje su ne samo školskim obrazovanjem bile za to osposobljene nego su im jezici koje su poučavale biti uglavnom materinji jezici. Učenice su ne samo na školskim satovima učile njemačku, francusku, talijansku, englesku gramatiku i pravopis, nego je bila obveza da se u internatima za vrijeme objeda međusobno razgovara na tim jezicima. Tako se za ručkom govorilo njemački, a za večerom francuski. Dakako, bilo je moguće imati učiteljice kojima su to bili materinji jezici, jer su uršulinke bile internacionalna zajednica raširena diljem Europe i sestre su za škole u Hrvatskoj mogle tražiti potreban kadar od svoje vrhovne uprave. ${ }^{15}$

Uz ovaj primjer svakako vrijedi spomenuti i nastavu tjelesnog odgoja, za koju nam je teško zamisliti da je u ono vrijeme mogla postojati na takvoj razini, pogotovo ako znamo da se je riječ o učiteljicama koje su bile klauzurne redovnice. Tjelesni odgoj isticao se zbog zdravlja učenica, ali i zbog odgoja pristojnosti, te je obuhvaćao gimnastiku i ples, pod kojim se opet shvaćala poduka estetske gimnastike, hodanje, nauk o pristojnosti držanja i vladanja, dvoranski i narodni plesovi. Uz visoko organiziranu nastavu tjelesnog odgoja, gdje su se ispiti iz tjelovježbe polagali i pred izaslanicima vlade, škola je imala i svoje školsko igralište (gombalište), a djevojčice su ljeti organizirano vođene na kupanje i na tjedne šetnje izvan samostana, dok je zimi za njih uređivano klizalište. Nastavu tjelesnog odgoja ponekad su izvodili vanjski nastavnici, ali su predavale i brojne redovnice i redovničke pripravnice. ${ }^{16}$

Dakako da su škole i konvikt bili pod budnim praćenjem carskoga dvora i državne uprave. Oni su prosvjetne napore uršulinki poticali, podupirali, ponekad i financijski pomagali, ali u svakom slučaju budno nadzirali. Tako primjerice carica Marija Terezija 1777. godine izdaje povelju utemeljenja »Carskog konvikta« sa zakladom za osam djevojaka te uzdržavanje samostanske zgrade. ${ }^{17}$ Te je godine konviktska škola bila podignuta na rang više djevojačke škole u trajanju od šest godina, a njoj je bila pridružena i tzv. glavna škola za odgoj učiteljica za cijelu Hrvatsku. Ali je carica tražila i iscrpna izvješća iz škola, slala nadzornike, izdavala dekrete i zahtjeve o različitim prilagodbama odgojnog i prosvjet-

\footnotetext{
14 Usp. Isto, str. 90-91.

${ }^{15}$ Usp. Isto, str. 98-100. Također usp. Mihaela Ankica DUMBOVIĆ, »Obrazovno-odgojno djelovanje varaždinskih uršulinki«, 300 godina uršulinki u Varaždinu, str. 227-241., ovdje 238.

${ }^{16}$ Usp. Hrvatske uršulinke, str. 105-108.

17 Usp. A. CUVAJ, Građa za povijest školstva I, str. 402.
} 
nog rada. Samostan je prihvaćao prilagodbe te je tako izbjegavao bilo kakve konflikte s carskim dvorom, njegove čistke i moguće zabrane. Dapače, na mnoge su odredbe, prema kojima je trebalo podizati razinu kvalitete u školama, uršulinske škole bile unaprijed spremne, jer su te redovnice u svojim školama redovito činile više i bolje od onoga što su trenutne odredbe zahtijevale pa su gotovo svim odredbama na polju prosvjetnoga rada već unaprijed udovoljavale, dakle u odnosu na njih one su išle korak naprijed. Budući da su po svojim pravilima internacionalnog karaktera uršulinke u to vrijeme imale nastavni sustav koji ih je povezivao s tadašnjom Europom, pa i s Amerikom, mogle su biti ispred pozitivnih državnih zakona i davati bolju i opsežniju naobrazbu od onoga što je bilo traženo i državnim zakonima propisivano. ${ }^{18}$

Ono što je za duh uršulinskih škola bilo još važnije, jest činjenica da je u njima velika važnost pridavana odgoju. Pritom se veoma isticala važnost osobnog primjera odgojiteljica, a značajno se naglašavala i trajna izobrazba redovnica koje su bile učiteljice. Kako su to bile redovnice s obvezom stroge papinske klauzure, u svoje su škole i samostane pozivale državne komisije pred kojima su dodatno polagale potrebne ispite u svrhu stručnog usavršavanja. A poznato je da su se neke od njih uz pedagoški rad bavile i glazbenim i književnim stvaralaštvom, kao i izradom sakralnoga ruha, čime su također davale dobar primjer svojim učenicama. Uršulinke su u svoje škole ulagale velike napore te se slobodno može reći da su njihove škole bile na takvim razinama kakve se ni stoljećima kasnije teško mogu dostići ili nadmašiti. Zbog toga su te škole dugo vremena bile veoma cijenjene i u njima su obrazovane i odgojene mnoge znamenite hrvatske žene.

Iz svega navedenoga o uršulinskim školama, iako su navedeni samo mali i nasumično izdvojeni ulomci bogatoga pedagoškog djelovanja, dade se zaključiti da je uršulinski odgojno-obrazovni sustav i njihovo zauzeto djelovanje u Hrvatskoj 18. i 19. stoljeća po motivaciji, pedagoškim metodama, zauzetosti, širini i kvaliteti, obrazovanju nastavničkoga kadra, ali i po prostorno-vremenskoj koegzistenciji najsličniji isusovačkom odgojno-obrazovnom djelovanju. Stoga se sasvim logično nameće pitanje o mogućoj suradnji tih dviju redovničkih ustanova, odnosno, budući da su isusovci u to vrijeme kao muški crkveni red svakako dominantniji i njihovo djelovanje intenzivnije, postavlja se pitanje o njihovu mogućem utjecaju na ustroj i djelovanje uršulinskih škola i uopće odgojno-obrazovno djelovanje tih redovnica.

Prema nekim ranijim istraživanjima usredotočenim uglavnom na školske knjige ${ }^{19}$ pokazano je da izravne suradnje isusovaca s uršulinskim školama u Varaždinu nije bilo ili je ona bila minimalna. Bila je svedena samo na rijetke pojedinačne slučajeve kratkotrajnoga nastavničkog djelovanja nekolicine profesora iz isusovačke gimnazije, kasnije varaždinske Državne gimnazije, u uršulinskim srednjim školama, kada i ako sestre nisu imale vlastitoga kadra za neke školske predmete, te nekoliko predavačkih aktivnosti vezanih uz rad Varaždinske gimnazijske ekstenze, koja se, iako u odgojnom smislu veoma značajna, smatrala dopunskim obrazovanjem izvan redovitoga obrazovnog procesa. Takvi se povremeni i kratkotrajni kontakti mogu zaista smatrati zanemarivim iznimkama ograničenog

${ }_{18}$ Usp. Hrvatske uršulinke, str. 98-99, 102-103.

19 Ovdje prije svega mislimo na rad: Siniša HORVAT, »Suradnja uršulinskih samostanskih škola i Varaždinske gimnazije«, 300 godina uršulinki u Varaždinu, str. 243-251. 
trajanja. Bilo je stoga zanimljivo pretražiti Prvu samostansku kroniku uršulinskog samostana, tražeći u njoj zapise o kontaktima isusovaca s uršulinkama, osobito u smislu očekivane suradnje na odgojno-obrazovnom području ili mogućih poticaja, savjeta, sugestija, te na taj način i utjecaja isusovaca na odgojno-obrazovni rad tih redovnica. ${ }^{20}$

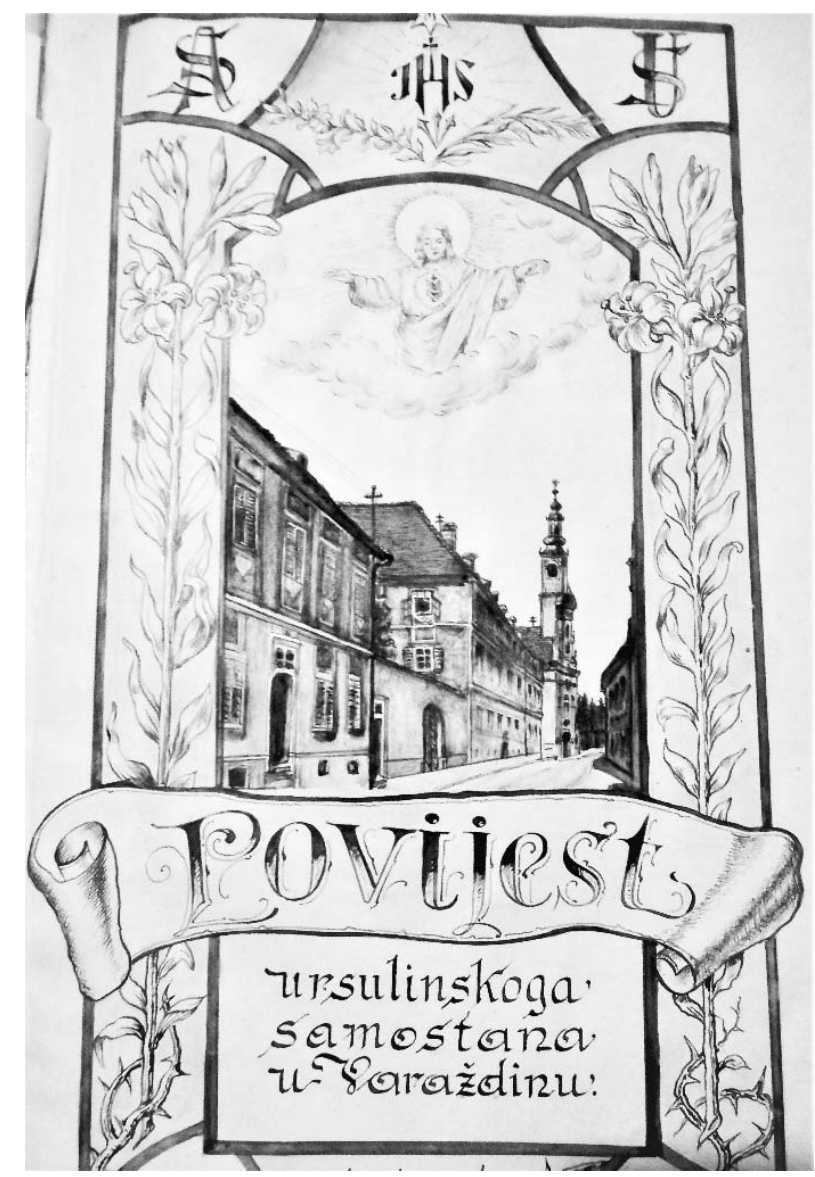

${ }^{20}$ Prva samostanska kronika uršulinskog samostana (dalje: Kronika I) bilježi vrijeme od dolaska sestara u Hrvatsku do 1900. godine. Čuva se u Arhivu uršulinskog samostana kao Povijest uršulinskoga samostana u Varaždinu. Zapravo je riječ o restauriranoj Kronici jer se izvorna izgubila. Naime, neka od poglavarica posudila ju je nekom kanoniku, ovaj je umro, a Kronika nikada nije vraćena, te se poslije zagubila o nije mogla biti pronađena. Restauriranu Kroniku, koja je zapravo povijest varaždinskog samostana od dolaska sestara do 1900. godine, napisala je s. Terezija Horvat, učiteljica i ravnateljica škole u Varaždinu, na temelju dugogodišnjih istraživanja u Nadbiskupskom arhivu i po drugim izvorima. Završila je pisanje 27. travnja 1960. godine. Kronika je pisana hrvatskim jezikom. Stranice su naknadno umetnute. Čuva se u Arhivu samostana u Varaždinu u Fondu Kronike, pod br. 1. Postoji i Kronika pod br. 2, koja obuhvaća razdoblje od 1820. do 1926. godine, ispočetka pisana na gotici njemačkim jezikom, a od 1915. godine hrvatskim jezikom. Ta je Kronika, osobito u prvom razdoblju, pisana puno oskudnije te nema izravnih podataka o suradnji s isusovcima. Sve te podatke zahvaljujem uršulinki s. Klaudiji Đuran, voditeljici samostanskog Arhiva u Varaždinu i povjesničarki varaždinskih uršulinki. 


\section{Sudjelovanje isusovaca u životu varaždinskih uršulinki prema Prvoj samostanskoj kronici uršulinskog samostana}

U samom početku djelovanja uršulinki, dok su još boravile u varaždinskom predgrađu, duhovne su im usluge činili lepoglavski pavlini, koji su imali posjed u neposrednoj blizini, a nedaleko su bili i čakovečki pavlini. Ipak, preseljenjem u sami grad sestre se smještaju i započinju svoju djelatnost točno nasuprot isusovačke crkve te je bilo i primjereno i očekivano da su, što zbog te prostorne blizine, što zbog bliske duhovnosti i sličnosti kršćanskoga apostolata, bile upućene na isusovce, koji su 75 godina prije njih došli u Varaždin i u njemu već bili razvili i snažnu duhovnost i snažan školski apostolat za mušku mladež. $\mathrm{O}$ svojevrsnom suživotu dviju redovničkih zajednica svjedoče i mnogi zapisi koji se mogu pronaći u Arhivu uršulinskog samostana, pa i Prve samostanske kronike. Prvi spomen isusovaca zabilježen u toj Kronici vezan je uz ime graditeljice samostana M. Ivane Gloss i jedan zanimljiv podatak iz njezina života. Spominje se da je bila protestantkinja te je u Bratislavi susrela isusovca o. Brauna, koji joj je pomogao od obraćenja do ostvarenja zvanja u uršulinskom redu. ${ }^{21}$

U Kronici je zabilježeno da se isusovačka pomoć i podrška sestrama uršulinkama očitovala i kroz materijalnu pomoć, ${ }^{22}$ ali prije svega kroz pružanje duhovnih usluga njima kao redovnicama, osobito kroz brojne propovijedi, nagovore, duhovne vježbe i obnove te sakramentalni život. Isusovci su bili duhovni pratitelji sestrama u svim važnim događanjima redovničke zajednice: kod redovničkih oblačenja, zavjeta, jubileja ili izbora samostanskih poglavarica. O duhovnoj djelatnosti isusovaca u uršulinskom samostanu u Varaždinu postoje mnoge ispisane stranice uvezane u različite knjige. Uglavnom je riječ o sestarskim zapisima propovijedi ili osobnim bilješkama s duhovnih vježbi i nagovora koje su isusovci održavali sestrama. Neke od tih bilješki nastajale su i nakon što je službeno 1773. godine ukinuta Družba Isusova te su isusovci ostali djelovati u Varaždinu kao dijecezanski svećenici, ali sestre uz te propovijedi i nagovore bilježe imena svećenika nazivajući ih i dalje isusovcima. Osim tih od sestara zabilježenih propovijedi i nagovora, postoje i pismeno izloženi nagovori i razni drugi teološki sadržaji koje su očito u knjige sabirali pojedini isusovci koji su ih i pisali. Među takvima se ističe katekizam o. Jurja Muliha iz 1744. godine, posvećen velikom hrvatskom meceni i biskupskom izaslaniku opatu Sigismundu Szinerspergu. Jedna od značajnijih zbirki takvih sadržaja je i rukopisna knjiga, čiji je autor najvjerojatnije o. Franjo Ksaver Zsemerer. U nekoliko manjih svezaka sačuvane su i čitave duhovne vježbe o. Antonia Auera. ${ }^{23}$ Ti su teološki sadržaji, propovijedi i nagovori veoma značajni jer su kroz njih isusovci uršulinkama pružali ne samo duhovnu brigu nego i temeljitiju teološku izobrazbu, što je tim redovnicama bilo izuzetno značajno kako za osobnu izgradnju tako i za poučavanje jer u to vrijeme nije postojala mogućnost teološke

${ }^{21}$ Usp. Kronika I, str. 14.

22 Tako se na početku uršulinske prisutnosti u Varaždinu spominju o. Baumgartner i o. Genua, koji su sestrama materijalno pomagali, novcem i živežnim namirnicama. Usp. Kronika I, str. 24.

${ }^{23}$ Osim svezaka propovijedi i nagovora koje su isusovci držali uršulinkama i koji se čuvaju u uršulinskom samostanu, neki se takvi rukopisi zasigurno mogu naći i po isusovačkim samostanima. Tako u Drugoj samostanskoj kronici uršulinskog samostana (1820. - 1926.) na str. 81. za 1913. godinu stoji sljedeća bilješka: »2. veljače poklonila je Časna majka (Josipa pl. Köröskenyi) uz dopuštenje viših poglavara časnim ocima isusovcima u Travniku više rukopisa s propovijedima i razmatranjima otaca isusovaca iz 18. stoljeća.« 
izobrazbe žena, a i teološke su knjige bile teško dostupne. Svojim svećeničkim djelovanjem isusovci su ostavili dubok trag na duhovnosti i pobožnosti sestara uršulinki. Tako su one još iz matičnog samostana u Bratislavi kao dio vlastite duhovnosti formirane od isusovaca donijele štovanje Srca Isusova kao i pobožnost prema misionaru Franji Ksaverskom. Osim toga, isusovci su u uršulinskoj crkvi propovijedali na njemačkom i hrvatskom jeziku, što je vidljivo iz mnogih sačuvanih propovijedi, te su na taj način bili duhovnici ne samo sestrama nego i odgojitelji savjesti i prenositelji kršćanskih načela svima koji su u tu crkvu zalazili.

Prva samostanska kronika uršulinskog samostana također bilježi duhovno djelovanje otaca isusovaca i njihovu svećeničku djelatnost u uršulinskom samostanu. Na stranicama te Kronike nalazimo brojna imena isusovaca koji su kroz svoje propovijedi i nagovore oblikovali duhovni život varaždinskih uršulinki: Huber, Gerssler, Kauffer, Alojzije Merz, Đuro Gajšek, Ignacije Haan, Ignacije Langettel, Franc Antun Gusmann, Ignacije Puz, Maksimilijan Spilhofer... Osim ovih čija imena susrećemo na stranicama Kronike, sestre su i u druge posebne bilježnice bilježile imena mnogih drugih svećenika, njihove službe i djelovanje u svom samostanu. ${ }^{24}$

Najčešći spomeni isusovaca u Prvoj kronici su oni vezani uz izbor samostanskih poglavarica ili uz tada veoma važne kanonske vizitacije. Isusovci su, naime, sve do ukinuća Družbe sudjelovali kod izbora uršulinskih poglavarica, držali duhovne vježbe koje su prethodile izborima i propovijedali novoizabranim poglavaricama, a bili su uglavnom i redovni pratioci biskupa ili njegova izaslanika prigodom kanonskih vizitacija. Čini se da je dobra suradnja s isusovcima u takvim prigodama bila praksa u uršulinskim samostanima i prije dolaska u Hrvatsku. To potvrđuje i jedna zabilješka u Kronici, koja se odnosi na pismo M. Ivane Gloss, najbliže suradnice M. Ane Julijane Drašković, biskupu Emeriku Eszterhazyju 2. studenog 1711. godine: »Ponizno molim Vašu biskupsku Visost da nam dozvoli što prije opravdani izbor glavarice. [...] U potpunoj podložnosti očekujemo Vašu Visost da će osobno doći, ili milostivo odrediti, da netko drugi taj izbor obavi. Mogao bi to biti vlč. gospodin Müller s još jednim svećenikom vrlo poštovane Družbe Isusove. Na taj smo način obavljali sve izbore u Požunu. $\ll^{25}$ Izbor se tada nije dogodio, ali jeste 1715 . godine, kada je za poglavaricu izabrana M. Ivana Gloss, a izboru je prethodila vizitacija »s jednim isusovcem ${ }^{26}{ }^{26}$

Također se i uz kasnije vizitacije i izbore spominju imena otaca isusovaca. Tako uz nadnevak 16. kolovoza 1722. govori se o trećoj vizitaciji i spominje se opat Grgur Šubarić, koji je najvećim dijelom platio izgradnju crkve Isusova rođenja, u pratnji rektora kolegija o. Genue. Tada je izabrana poglavarica M. Bernardina grof. Esterhazsy (1722. - 1730.). ${ }^{27}$

\footnotetext{
${ }^{24}$ Tako je primjerice sestra M. Gabrijela pl. Orešković u posebnu bilježnicu zapisivala svećenike i njihove službe. Nabrojila je ispovjednike do ukidanja Družbe, potom kvatrene ispovjednike te one koji su davali duhovne vježbe i obnove. Uz imena navedena u Kronici, tu nailazimo još i sljedeća: Braun, Zenner, Beller, Bock, Predragović, Zabeo, Brixi, Puntigam, Szinko, Hammerl, Vrtovac, Bruno Foretić, Ivan Kozelj, Flodin, Strižić, Miroslav Vanino, Rabadžija, Horman, Jambreković, Belić, Šimeta, Katalinić, Jäger...

${ }_{25}$ Kronika I, str. 31.

${ }^{26}$ Isto, str. 46.

${ }_{27}$ Usp. Isto, str. 56.
} 


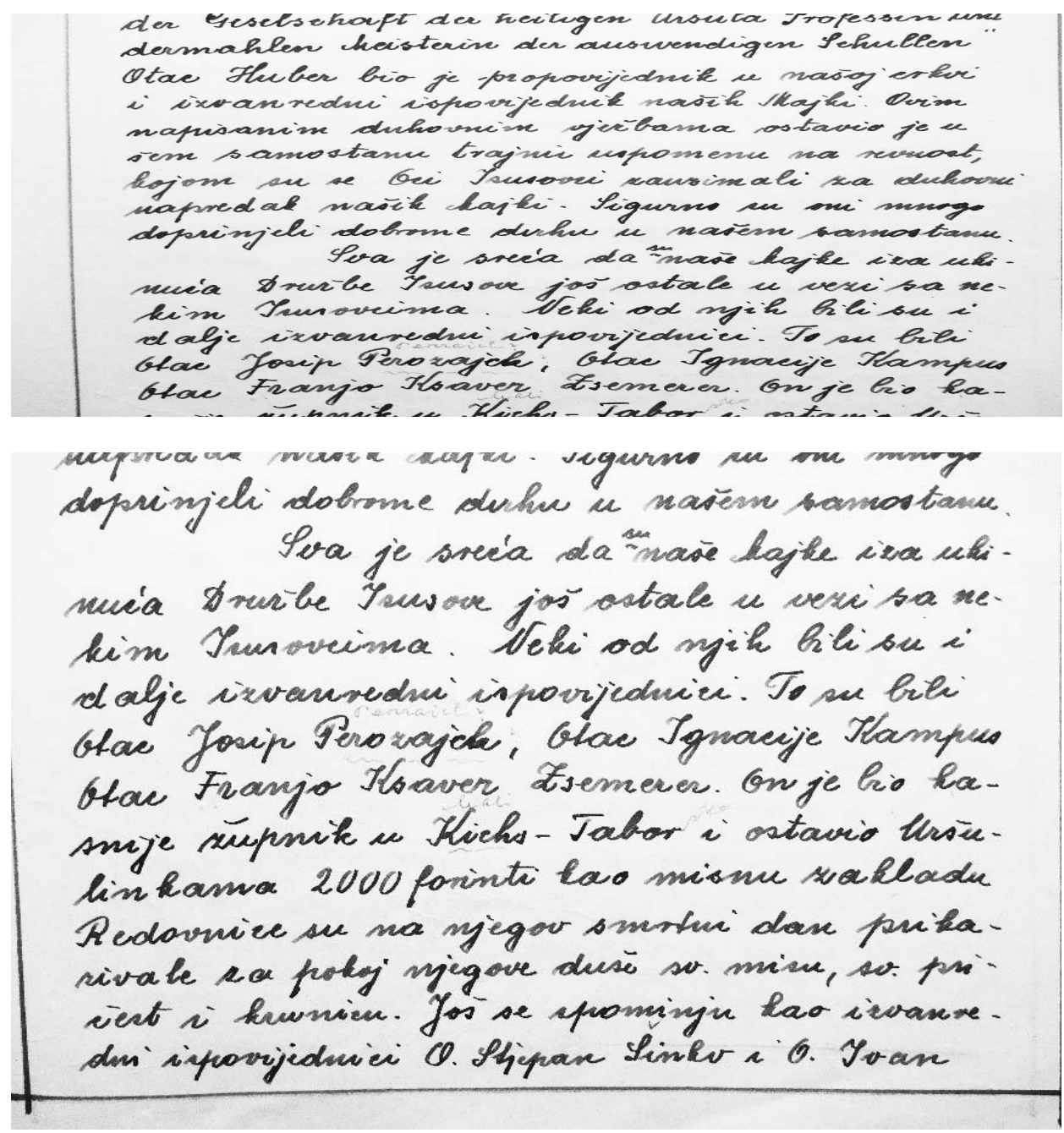

Kronika I, str. 107.

Uz vizitaciju koja je završila 19. travnja 1749. godine napisano je da opat Sigismund Szinersperg dolazi s o. Cernićem, ${ }^{28}$ a uz vizitaciju iz 1752. godine zabilježeno je da su u pratnji zagrebačkog kanonika bila dvojica isusovaca, rektor Antonio Gallyuf i o. Ignacije Läuttner, njemački propovjednik u uršulinskoj crkvi i izvanredni ispovjednik sestara. ${ }^{29} \mathrm{Uz}$ reizbor poglavarice Anđele Wintershofer (1752. - 1758.), koji je bio 1755. godine vizitaciju su obavili zagrebački kanonici Adam Stjepanić i Josip Gallyuf te isusovci rektor Andrija Sallay i Augustin Huber, poznat i po tome što je sestrama ostavio nekoliko svezaka

\footnotetext{
${ }^{28}$ Isto, str. 77.

${ }^{29}$ Isto, str. 79.
} 
propovijedi i duhovnih vježbi. Otac Huber je tom prigodom održao i uvodni govor. ${ }^{30}$ Isti se o. Huber spominje i uz izbor poglavarice Kajetane Erdreich 1758. godine, ${ }^{31}$ a na njezina reizboru 13. rujna 1764. godine bili su nazočni zagrebački generalni vikar Ivan Kukuljević i rektor kolegija isusovac Matija Varašić. ${ }^{32}$

Isusovci su bili aktivni sudionici samostanskoga života varaždinskih uršulinki, koji se uz navedene aktivnosti očitovao i kroz razne duhovne i liturgijske proslave te obilježavanja samostanskih obljetnica. Tako se bilježi da je proslavi beatifikacije sv. Anđele, utemeljiteljice uršulinskoga reda, koja je bila 30. travnja 1768., prethodila trodnevnica koju su vodili isusovci, ${ }^{33}$ a također i uz 100. obljetnicu dolaska sestara 1803. godine samostanskoj su proslavi između ostalih nazočili i isusovci. ${ }^{34}$

Kronika bilježi i jedan nemio događaj kada je 1806. godine netko oklevetao sestarski samostan te isusovac o. Đuro Gajšek brani sestre pred biskupom Vrhovcem. ${ }^{35}$ Kleveta, koje su uglavnom proizlazile iz zavisti i želje da se sestrama onemogući njihov školski rad bilo je i kasnije, a sestre svjedoče da su ih svećenici, među kojima najčešće isusovci, uvijek branili promatrajući plodove njihova odgojnog rada. Na takvu osjetljivost i susretljivost isusovaca prema sestrama i sestre su uzvraćale istim sestarskim suosjećanjem i molitvenim praćenjem njihova života i sveukupne svećeničke i redovničke djelatnosti. Tako se na samom kraju Prve kronike spominje gradnja samostana otaca isusovaca u Zagrebu, zbog koje sestre iskazuju veliku radost. ${ }^{36}$ Tim iskazom i završava opis suradnje između tih dvaju redova. Smrću zadnjeg isusovca u Varaždinu duhovnu brigu redovnih i izvanrednih ispovjednika uglavnom su preuzeli franjevci i kapucini, a posebno nadbiskupski povjerenici koji su do stupanja varaždinskih uršulinki u Rimsku uniju (1927. godine) vodili i sve važnije poslove samostana.

Nakon svega navedenog o bliskom suživotu isusovaca i varaždinskih uršulinki, bogate svećeničke djelatnosti u uršulinskom samostanu i crkvi, još više iznenađuje činjenica da u Prvoj samostanskoj kronici uršulinskog samostana ne nalazimo nikakvih tragova koji bi ukazivali da su isusovci imali bilo kakav utjecaj na uršulinsku školsku djelatnost ili njihovo odgojno djelovanje. Kronika potvrđuje da, iako su i duhovnost i pedagoška načela isusovaca i uršulinki bili veoma srodni, isusovci se ni na koji način nisu miješali u ustroj i djelovanje uršulinskog odgojno-obrazovnog rada ili njihovih škola.

\section{Zaključak}

Prva samostanska kronika uršulinskog samostana u Varaždinu, koja bilježi podatke iz života tih redovnica od njihova dolaska u Varaždin 1703. godine sve do 1900. godine, svjedoči o duhovnoj i karizmatskoj bliskosti isusovaca i uršulinki, o bogatoj duhovnoj

\footnotetext{
${ }^{30}$ Usp. Isto, str. 79-80.

31 Usp. Isto, I, str. 86.

32 Usp. Isto, str. 105.

33 Usp. Isto, str. 103.

34 Usp. Isto, str. 151.

${ }_{35}$ Usp. Isto, str. 174-175.

36 Usp. Isto, str. 297.
} 
djelatnosti isusovaca u uršulinskom samostanu i crkvi, o obostranom uvažavanju i poštovanju, čak i materijalnom podupiranju, ali ne donosi nikakve podatke koji bi upućivali na zaključak da bi se isusovci i na koji način, pa ni sugestijama, poticajima ili savjetima, miješali u uršulinski odgojno-obrazovni rad ili na bilo koji način u njemu izravno sudjelovali. Iz cjelokupnoga konteksta kako te kronike tako i drugih izvora dadu se izvući sljedeći zaključci:

1. Isusovci su u razdoblju koji opisuje Prva samostanska kronika uršulinskog samostana imali dovoljno posla i punu zaokupljenost u svojim školama, osobito gimnaziji, kao i u svom svećeničkom pastoralnom radu. Uršulinke u tom razdoblju imaju dovoljno izvrsnoga vlastitog kadra tako da su samo sporadično i u nekim kasnijim razdobljima trebale pomoć profesora iz isusovačkih škola. Osim toga, uršulinke su u to vrijeme bile pod strogom klauzurom, što se odražavalo i na njihove škole, tako da su ipso facto za višeg poglavara imale biskupova izaslanika, koji je s jednim ili više duhovnika jedini u njihovim školama smio predavati kršćanski nauk djevojkama i djevojčicama. ${ }^{37}$

2. Drugi zaključak čini se ipak puno važniji. Naime, iz svega proizlazi da su isusovci, uz svu sličnost i preklapanje duhovnosti i pedagoških načela isusovaca i uršulinki, dobro razumjeli i postojeće razlike i specifičnosti uršulinskih škola i njihovih odgojnih metoda te su svojim izravnim nemiješanjem pokazivali zapravo kako izuzetno poštuju sestre i njihov rad. Vidjeli smo, istina, da se Pravila odgojnih metoda uršulinskih škola (Règlements iz 1960.) naslanjaju na Program studija Družbe Isusove (Ratio studiorum), no po svemu sudeći sličnost se više odnosila na vanjsko i sadržajno ustrojstvo škola i školskih programa, dok je nutarnja odgojna metoda u uršulinskim školama izravno slijedila spise njihove utemeljiteljice, sv. Anđele Merici (Pravilo iz 1535., Spomeni $i$ Ostavštine iz 1539.), koji su više zahvaćali u odgoj karaktera i osobnosti, ne zanemarujući dakako ni obrazovnu razinu. Upravo su se tom odgojnom metodom i pedagoškim načelima, koji su izrasli prije svega iz dubokog kršćanskog uvjerenja, služile i varaždinske uršulinke u svojim školama. Slijedeći svoju temeljnu redovničku karizmu odgojno-obrazovnog djelovanja, uršulinke su prirodno povezivale kršćansko i redovničko zvanje i poslanje na području prosvjetnoga rada te je upravo prvo bilo temelj drugomu i davalo mu veličanstvene dimenzije. Na temelju podataka iz samostanske kronike može se zaključiti da su isusovci kao duhovnici sestara sve to dobro uočavali i podržavali. Na temelju intenzivnoga duhovnog suživota zabilježenog u Prvoj kronici, njihovo se izravno nemiješanje u školski i odgojni rad uršulinki nikako ne može protumačiti kao pasivno distanciranje, nezainteresiranost za pitanje obrazovanja žena ili svojevrsna nebriga za sestarsko odgojno-obrazovno djelovanje. Upravo suprotno. Iz svega proizlazi da su isusovci imali veliko povjerenje u odgojni i školski rad uršulinki i da su prema tom djelovanju pokazivali veliko poštovanje te su sestrama upravo stoga ostavljali potrebnu

\footnotetext{
37 Što se tiče pouka u kršćanskom nauku, ovdje susrećemo jedan fenomen u crkvenim odredbama vezan za uršulinke. Naime, njima su biskupi već za vrijeme Tridentskog koncila povjeravali obučavanje vjeronauka u »Nedjeljnim školama kršćanskog nauka«. No kad su 1612. godine u Parizu od Družbe postale Red sv. Uršule i od Crkve kao zadatak dobile katoličke škole, izgubile su pravo naučavanja katekizma, koje su od tada preuzeli svećenici. Za taj podatak zahvaljujem također s. Klaudiji Đuran, koja se izbližega bavila proučavanjem povijesti i karizme uršulanskog reda.
} 
autonomiju i slobodu. K tomu, dobro su uočavali da temelj takva rada i zauzetosti leži u kršćanskim načelima i uvjerenjima koja proizlaze iz redovničkoga posvećenja te su prepoznali da je njihov istinski doprinos uršulinskoj karizmi podupirati i jačati sestre $u$ njegovanju dubokog vjerničkog i redovničkog života i kršćanske duhovnosti. Tako su upravo svojom propovjedničkom djelatnošću i posredovanjem teoloških sadržaja kroz svećeničke nagovore i duhovne vježbe najviše podupirali odgojno-obrazovni rad varaždinskih uršulinki.

3. Zbog svega iznesenog, može se na kraju slobodno reći da su uršulinke svojim odgojnoobrazovnim i školskim radom, a isusovci svojim nenametljivim podupiranjem toga rada i svećeničkim djelovanjem na izgradnji i jačanju kršćanskoga uvjerenja kod sestara $i$ njihovih odgajanica, bile preteče i zamašnjak ne samo obrazovanja nego i cjelovite afirmacije žene koju, nažalost, ni naše vrijeme još nije istinski doseglo, a afirmacijom žene pozitivno utjecali na cjelovitiji razvoj sveukupnog društva u Hrvatskoj onoga vremena. O tome svjedoče brojni spisi uršulinskog samostana u Varaždinu, pa i Prva samostanska kronika.

\author{
SUMMARY \\ JESUITS AND THEIR COOPERATION WITH THE SISTERS OF ST URSULA \\ ACCORDING TO THE FIRST CHRONICLE OF THE MONASTERY \\ OF ST URSULA IN VARAŽDIN
}

Author discusses early history of educational work of sisters of St Ursula order in Varaždin, from their arrival in 1703, until the beginning of the twentieth century. Namely, their work consisted of educational and school work that, in comparison with contemporary European and Croatian standards, was way ahead of the time. Ursuline pedagogical work was based on the manuscripts of the order's founder St Angela de Merici and Jesuits' regulation on high and higher schools Ratio studiorum. Since these two ecclesiastical orders had similar religious and educational approach in their work, and especially since these orders coexisted in Varaždin in the eighteenth and nineteenth centuries, author rises question whether these two ecclesiastical orders cooperated in their educational and pedagogical activities; or even whether Jesuits influenced on organization and activities of Ursuline schools and Ursuline educational doctrine. The investigation of the first chronicle of the Ursuline monastery in Varaždin, which covers timeframe from the period when sisters of St Ursula came to Croatia up to 1900, reveals a deep spiritual and charismatic contiguity between Jesuits and sisters of St Ursula and constant pastoral work of Jesuits within the Ursuline monastery and church. Still, the chronicle reveals also that the Ursuline sisters had a broad autonomy regarding their educational work.

KEY WORDS: sisters of St Ursula, Jesuits, Varaždin, Ursuline pedagogical principles, $18^{\text {th }}$ and $19^{\text {th }}$ century. 